University of Nebraska - Lincoln

DigitalCommons@University of Nebraska - Lincoln

7-23-2002

\title{
Impact of Irrigation on Midsummer Surface Fluxes and Temperature under Dry Synoptic Conditions: A Regional Atmospheric Model Study of the U.S. High Plains
}

\author{
Jimmy O. Adegoke \\ Colorado State University - Fort Collins \& University of Missouri-Kansas City, adegokej@umkc.edu \\ Roger A. Pielke Sr. \\ Colorado State University, Fort Collins \\ J. Eastman \\ Colorado State University, Fort Collins \\ Rezaul Mahmood \\ Western Kentucky University, Bowling Green \\ Kenneth G. Hubbard \\ University of Nebraska-Lincoln, khubbard1@unl.edu
}

Follow this and additional works at: https://digitalcommons.unl.edu/natrespapers

Part of the Natural Resources and Conservation Commons, Natural Resources Management and Policy Commons, and the Other Environmental Sciences Commons

Adegoke, Jimmy 0.; Pielke, Roger A. Sr.; Eastman, J.; Mahmood, Rezaul; and Hubbard, Kenneth G., "Impact of Irrigation on Midsummer Surface Fluxes and Temperature under Dry Synoptic Conditions: A Regional Atmospheric Model Study of the U.S. High Plains" (2002). Papers in Natural Resources. 1049.

https://digitalcommons.unl.edu/natrespapers/1049

This Article is brought to you for free and open access by the Natural Resources, School of at DigitalCommons@University of Nebraska - Lincoln. It has been accepted for inclusion in Papers in Natural Resources by an authorized administrator of DigitalCommons@University of Nebraska - Lincoln. 


\title{
Impact of Irrigation on Midsummer Surface Fluxes and Temperature under Dry Synoptic Conditions: A Regional Atmospheric Model Study of the U.S. High Plains
}

\author{
JiMMY O. ADEGOKE* \\ Cooperative Institute for Research in the Atmosphere, Colorado State University, Fort Collins, Colorado \\ Roger A. Pielke SR., AND J. EASTMan \\ Department of Atmospheric Science, Colorado State University, Fort Collins, Colorado \\ Rezaul MaHmoOD \\ Department of Geography and Geology, Western Kentucky University, Bowling Green, Kentucky \\ KenNeth G. HubBARD \\ School of Natural Resource Sciences, University of Nebraska-Lincoln, Lincoln, Nebraska
}

(Manuscript received 19 October 2001, in final form 23 July 2002)

\begin{abstract}
The impact of irrigation on the surface energy budget in the U.S. high plains is investigated. Four 15-day simulations were conducted: one using a 1997 satellite-derived estimate of farmland acreage under irrigation in Nebraska (control run), two using the Olson Global Ecosystem (OGE) vegetation dataset (OGE wet run and OGE dry run), and the fourth with the Kuchler vegetation dataset (natural vegetation run) as lower boundary conditions in the Colorado State University Regional Atmospheric Modeling System (RAMS). In the control and OGE wet simulations, the topsoil in the irrigated locations, up to a depth of $0.2 \mathrm{~m}$, was saturated at 0000 UTC each day for the duration of the experiment (1-15 July 1997). In the other two runs, the soil was allowed to dry out, except when replenished naturally by rainfall. Identical observed atmospheric conditions were used along the lateral boundary in all four cases.

The area-averaged model-derived quantities for the grid centered over Nebraska indicate significant differences in the surface energy fluxes between the control (irrigated) and the "dry" simulations. For example, a $36 \%$ increase in the surface latent heat flux and a $2.6^{\circ} \mathrm{C}$ elevation in dewpoint temperature between the control run and the OGE dry run is shown. Surface sensible heat flux of the control run was $15 \%$ less and the near-ground temperature was $1.2^{\circ} \mathrm{C}$ less compared to the OGE dry run. The differences between the control run and the natural vegetation run were similar but amplified compared to the control run-OGE dry run comparisons.

Results of statistical analyses of long-term (1921-2000) surface temperature data from two sites representing locations of extensive irrigated and nonirrigated land uses appear to support model results presented herein of an irrigationrelated cooling in surface temperature. Growing season monthly mean and monthly mean maximum temperature data for the irrigated site indicate a steady decreasing trend in contrast to an increasing trend at the nonirrigated site.
\end{abstract}

\section{Introduction}

\section{a. Background}

Anthropogenic influences on local and regional climate have received increased attention by the climate * Current affiliation: Department of Geosciences, University of
Missouri-Kansas City, Kansas City, Missouri.

Corresponding author address: Dr. Jimmy Adegoke, Dept. of Geosciences, 420K Robert Flarsheim Hall, University of Missouri-Kansas City, Kansas City, MO 64110-2499.

E-mail: adegokej@umkc.edu research community in the last decade as the demand for a more comprehensive understanding of the driving factors of global and regional climate change increased (Chase et al. 1996, 2000; Stohlgren et al. 1998; Heck et al. 2001; Eastman et al. 2001). Early observational studies (Marotz et al. 1975; Barnston and Schickendanz 1984; Alpert and Mandel 1986; Pielke and Zeng 1989) have shown that irrigation is one of the key anthropogenic factors influencing climate trends. Barnston and Schickendanz (1984), for example, found that irrigation increased precipitation in the Texas Panhandle when the synoptic condition provided low-level convergence and uplift, such that the additional moisture produced by 
irrigation was allowed to ascend to cloud base. Alpert and Mandel (1986) also found a deceasing trend in the diurnal surface wind and temperature with enhanced irrigation.

More recently, several attempts (De Ridder and Gallée 1998; Segal et al 1998) were made to use regionalscale atmospheric models to simulate the effect of irrigation on various planetary boundary layer (PBL) properties. Regional models are particularly suitable for quantifying irrigation-induced in situ and remote changes in climate elements such as precipitation because they are capable of resolving meso- $\alpha$ systems (i.e., systems of horizontal scale 200-2000 km). Segal et al. (1998) used the fifth-generation Pennsylvania State UniversityNational Center for Atmospheric Research (PSUNCAR) Mesoscale Model (MM5) (Grell et al. 1993) in their study of irrigated areas in North America. Their model results suggest an increase in the continentalaverage rainfall for the present irrigation conditions compared with those of past irrigation. De Ridder and Gallée (1998) used a European regional numerical model (Modèle Atmosphérique Régional-MAR) in their study of land-surface-induced regional climate change in southern Israel. They showed a reduction in the diurnal amplitude of temperature and wind speed when a semiarid surface is replaced by a partly irrigated one. The potential for moist convection also increased with surface moisture availability in their simulations.

The primary thermodynamic impact of irrigation is the repartitioning of the sensible and latent heat fluxes at the affected sites. Thus, an increase in irrigation or surface wetness reduces sensible heat flux while increasing evaporation and transpiration (Pielke 2001). The resulting additional moisture flux could enhance the characteristic moist static energy within the convective boundary layer (CBL) and consequently become thermodynamically more conducive to an increase in rainfall (Betts et al. 1994; Segal et al. 1998). In this study we use the Colorado State University Regional Atmospheric Modeling System (RAMS, version 4.3) to investigate the impact of irrigation on the surface energy budget and the convective potential in the U.S. high plains, emphasizing Nebraska. We take advantage of the two-way interactive grid nesting in RAMS, which allows local fine mesh grids to resolve small-scale atmospheric systems such as thunderstorm systems, while simultaneously modeling the large-scale environment of the systems on a coarser grid (Walko et al. 1995).

\section{b. Irrigation in Nebraska}

Over the last five decades, the total acreage under irrigation in the U.S. high plains increased from less than 3 million acres to over 20 million acres (Kuzelka 1993). The rapid development of irrigation in this area, which stretches from Nebraska through western Kansas to the Texas Panhandle, enabled the transformation of the area into one of the major agricultural areas of the

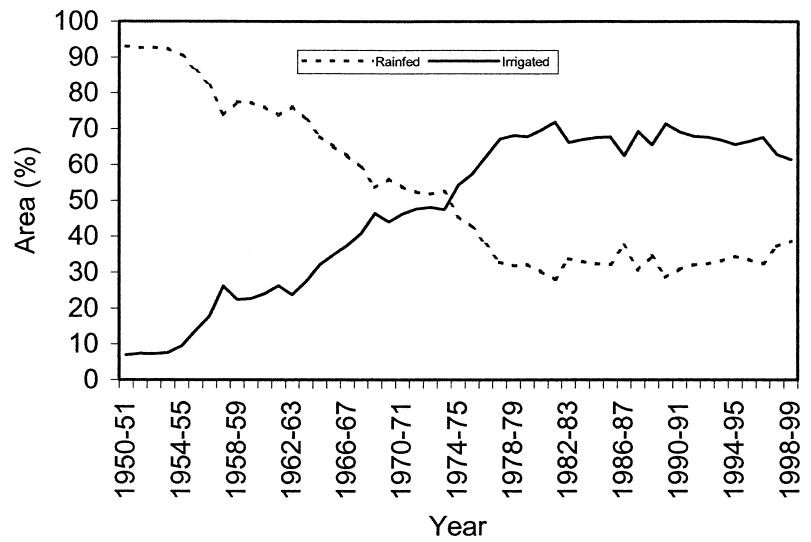

FIG. 1. Area (\%) of rain-fed and irrigated corn farming in Nebraska (1950-98).

United States. In Nebraska, as in much of the high plains, corn is the dominant crop cultivated during the warm season months (Williams and Murfield 1977). Irrigated corn, which represented about $10 \%$ of total corn producing areas during the early 1950s, now composes nearly $60 \%$ of the total corn producing areas in Nebraska (Fig. 1).

Data from the National Agricultural Statistics Services (NASS) of the United States Department of Agriculture (USDA) for York County in east-central Nebraska further underscore these changes. Between 1950 and 1998 the irrigated corn area in York County increased from 3500 ha to 80000 ha (a $2300 \%$ increase) while the rain-fed corn area declined rapidly during the same period (National Agricultural Statistics Service 1998). This rapid land use change was achieved largely by converting rain-fed corn areas to irrigation. Land use conversion of this magnitude could affect energy and moisture exchanges between the land surface and the lower atmosphere by altering transpiration and evaporation thus generating complex changes in the surface energy budget.

\section{Experimental design and model setup}

The meteorological model used in this study (RAMS, version 4.3) is constructed around a set of nonhydrostatic equations that address atmospheric dynamics and thermodynamics, plus conservation equations for scalar quantities such as water vapor and liquid mixing ratios. These equations are supplemented with a selection of parameterizations for turbulent diffusion, solar and terrestrial radiation, and moist processes including the formation of clouds. For a complete description of RAMS, the reader is referred to Pielke et al. (1992).

This version of RAMS includes the Land Ecosystem Atmosphere Feedback model, version 2 (LEAF-2) (Walko et al. 2000). This new submodel of RAMS represents the storage and vertical exchange of water and energy in multiple soil layers, including effects of temporary 
a)

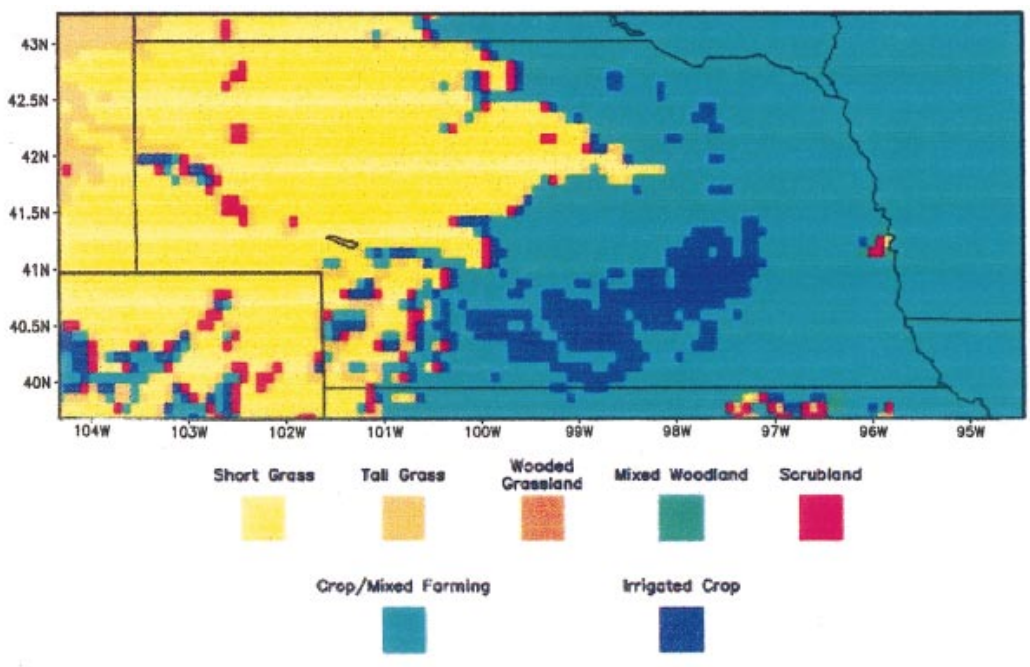

b)

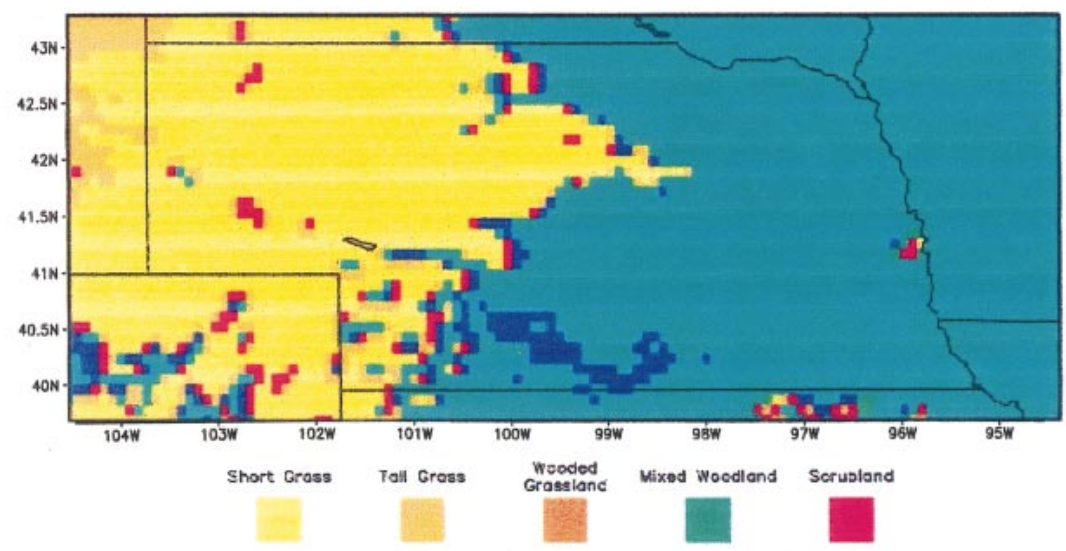

Crop/Mixed farming

Irriguted Crop

c)

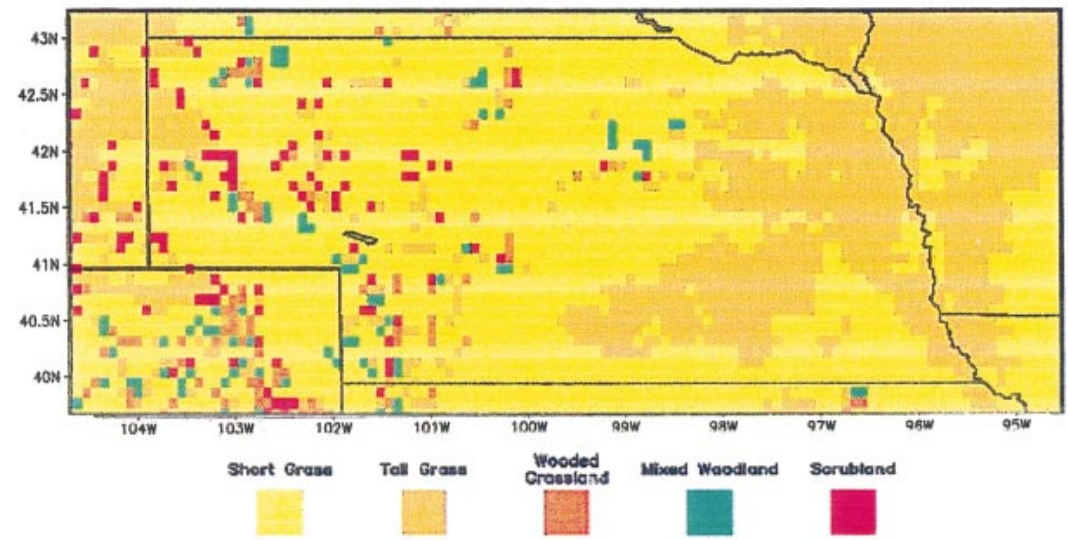

FIG. 2. Land cover datasets used for RAMS simulations: (a) 1997 Landsat and ancillary data irrigation, (b) OGE, and (c) Kuchler potential vegetation. 


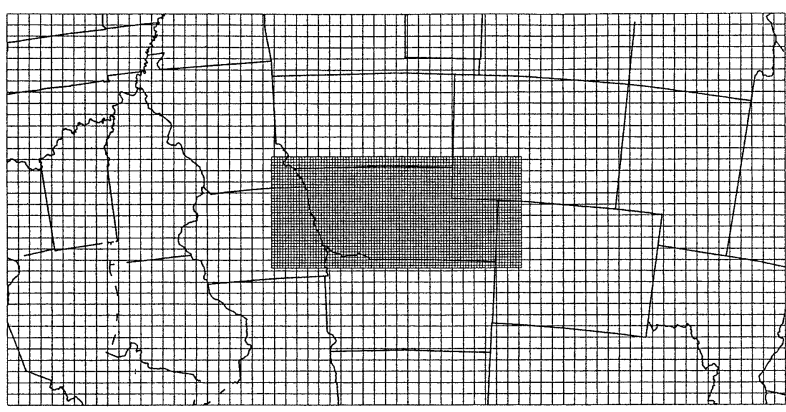

FIG. 3. Nested RAMS grids: coarse grid, 40-km grid spacing; fine grid, $10-\mathrm{km}$ grid spacing.

surface water, vegetation, and canopy air. Surface grid cells are divided into subgrid patches, each with a different vegetation or land surface type, soil textural class, and/or wetness index to represent subgrid variability in surface characteristics. Each patch contains separate
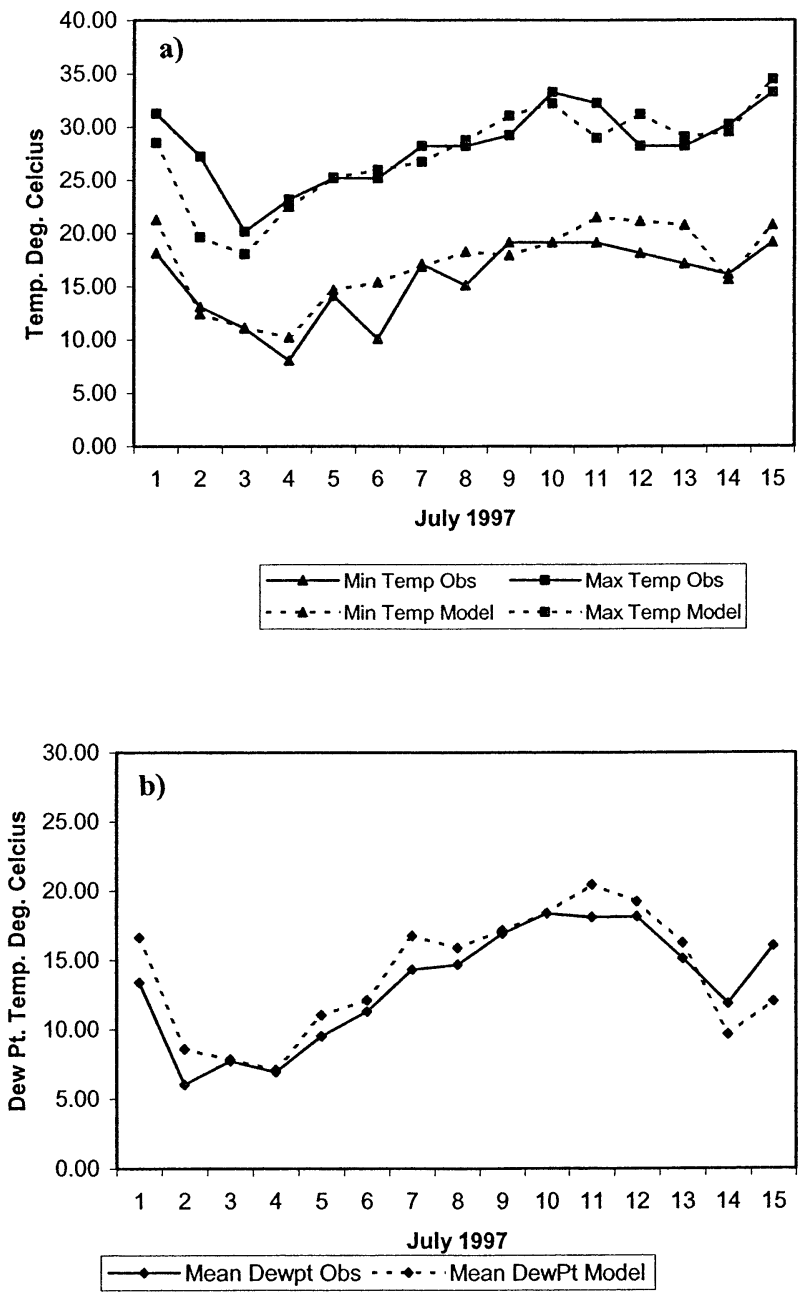

FIG. 4. (a) Observed min and max temp for Ainsworth municipal compared to model 2-m temp. (b) Average dewpoint temp and model dewpoint temp.
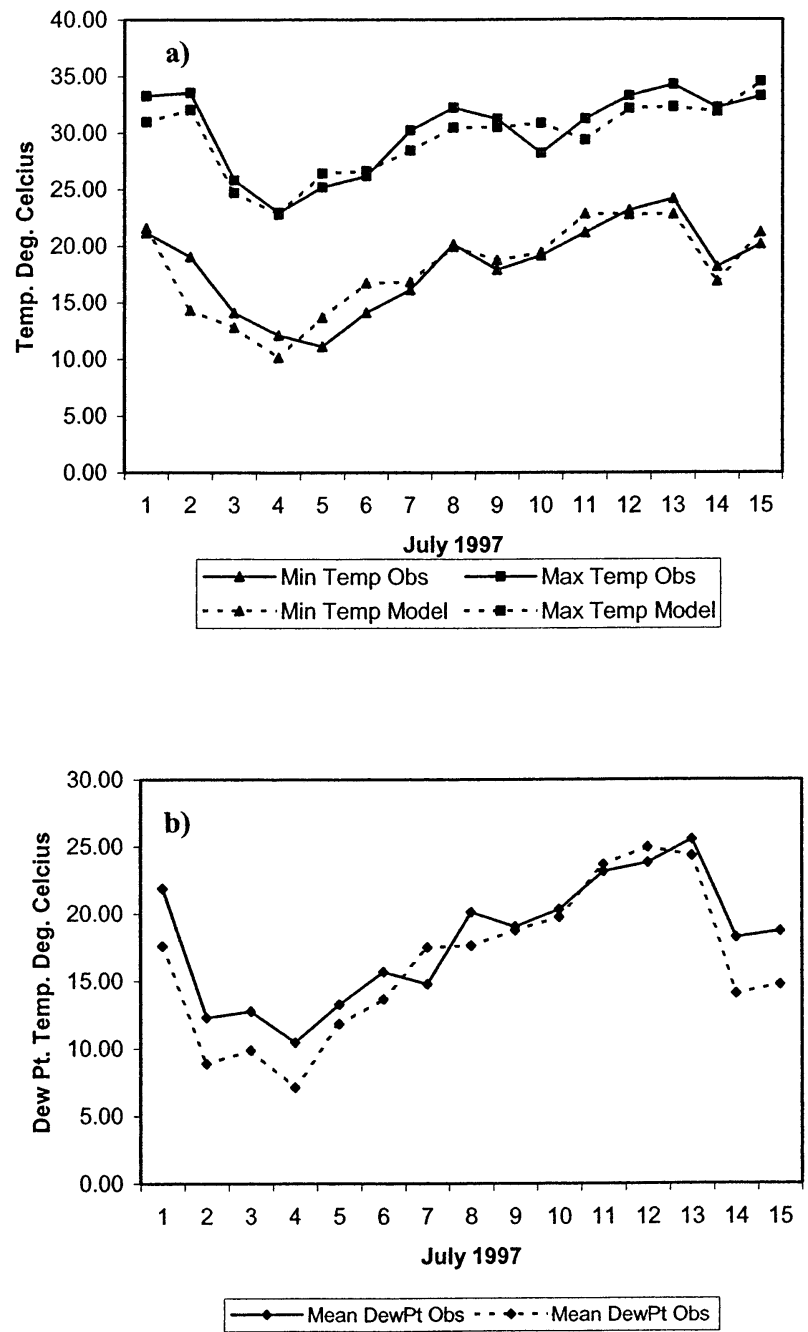

FIG. 5. Same as Fig. 4 for Omaha/Eppley Field.

prognosed values of energy and moisture in soil, surface water, vegetation, and canopy air. The grid cell exchange with the overlying atmosphere is weighted according to the fractional area of each patch. A hydrology model, based on Darcy's law for lateral downslope transport, exchanges subsurface saturated soil moisture and surface runoff between subgrid patches. LEAF-2 inputs standard land use datasets in order to define patches and their areas, as well as to obtain biophysical parameters for different vegetation types.

Our RAMS simulations consisted of four land use scenarios covering the 15-day period, 1-15 July 1997. The first scenario (control run) represented current farmland acreage under irrigation in Nebraska as estimated from 1997 Landsat satellite and ancillary data (Fig. 2a). The second and third scenarios (OGE wet and dry runs) represented the land use conditions from the Olson Global Ecosystem (OGE) vegetation dataset (Fig. 2b), and the fourth scenario (natural vegetation run) represented the potential (i.e., pre-European settlement) land 

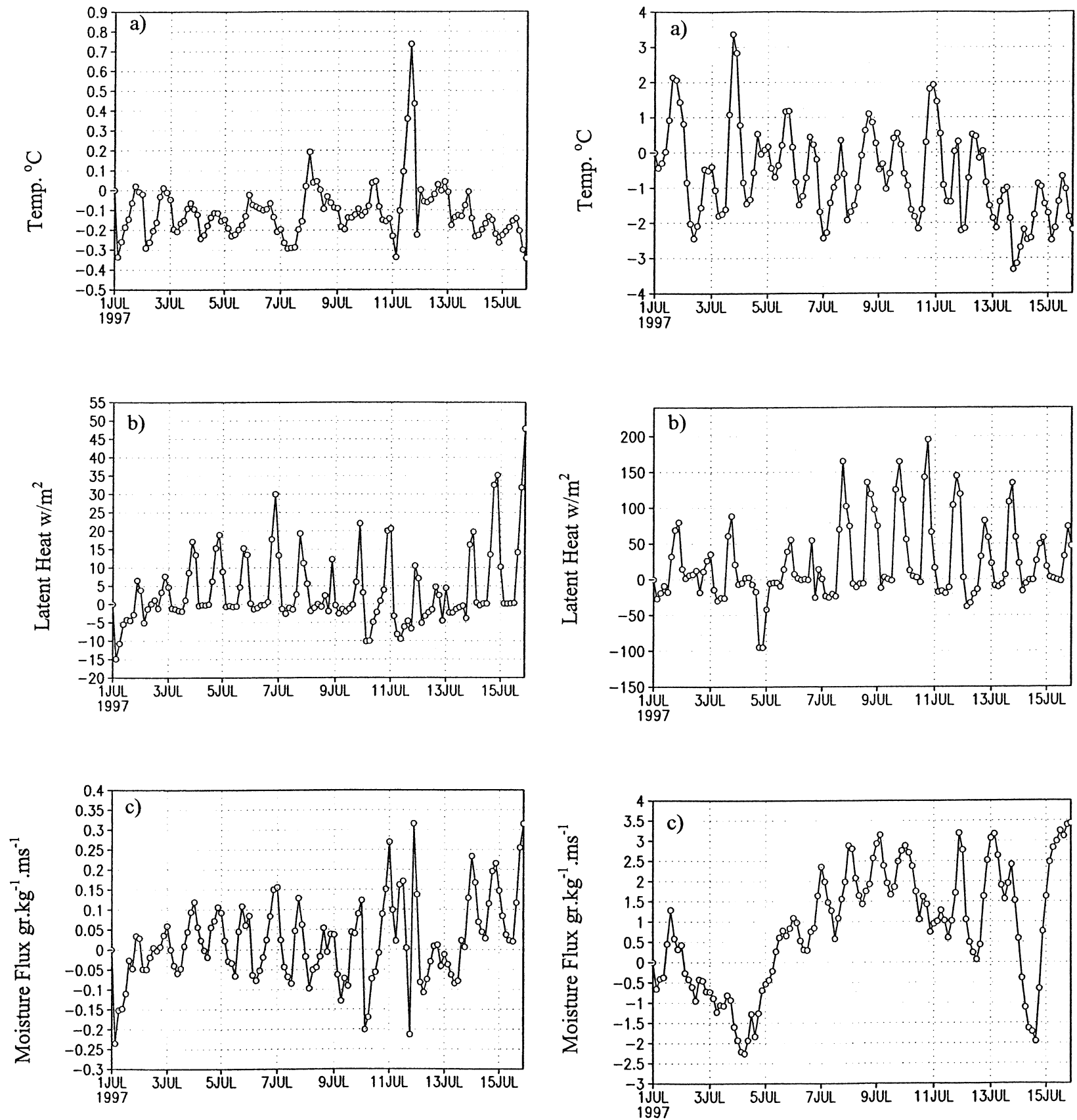

FIG. 6. Control minus OGE wet run inner-domain area-averaged (a) 2-m temp, (b) surface latent heat, and (c) moisture flux at $500 \mathrm{~m}$.

FIG. 7. Control minus OGE dry run inner-domain area-averaged (a) 2-m temp, (b) surface latent heat, and (c) moisture flux at $500 \mathrm{~m}$.

TABLE 1. Inner-domain area-averaged model parameters for 7-15 Jul 1997, including scenario comparisons (\% change).

\begin{tabular}{lcccc}
\hline \hline & Control & OGE (wet) & OGE (dry) & Natural vegetation \\
\hline Temp. $\left({ }^{\circ} \mathrm{C}\right)$ & 24.1 & $24.9(0.8)$ & $25.5(1.4)$ & $27.6(3.5)$ \\
Surface sensible heat $\left(\mathrm{W} \mathrm{m}^{-2}\right)$ & 76.2 & $79.8(4.7 \%)$ & $86.9(15 \%)$ & $98.4(29 \%)$ \\
Latent heat $\left(\mathrm{W} \mathrm{m}^{-2}\right)$ & 102.4 & $98.2(4 \%)$ & $74.5(35 \%)$ & $71.98(42 \%)$ \\
Vapor flux at $500 \mathrm{~m}\left(\mathrm{~g} \mathrm{~kg}^{-1} \mathrm{~m} \mathrm{~s}^{-1}\right)$ & 11.1 & $10.4(7 \%)$ & $9.1(22 \%)$ & $8.2(34 \%)$ \\
\hline
\end{tabular}



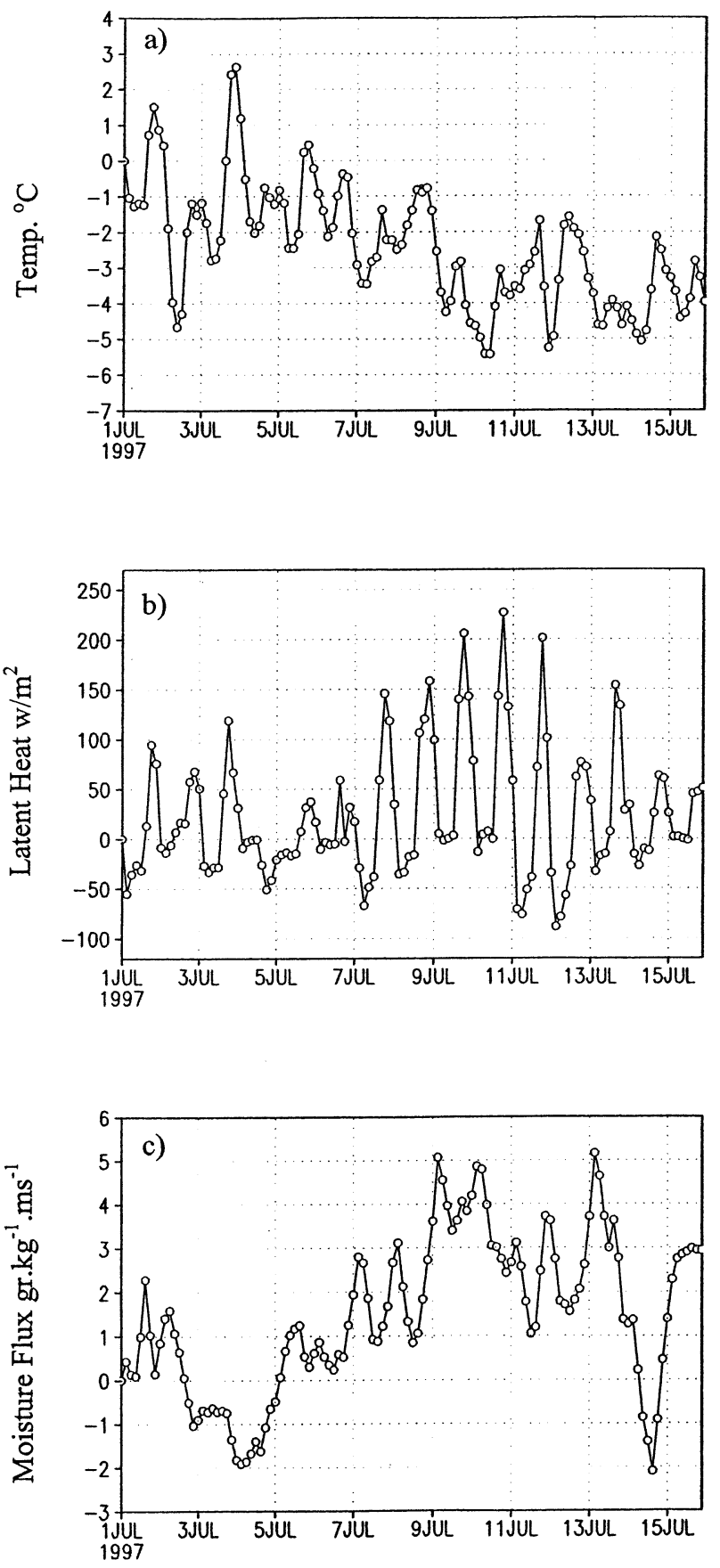

FIG. 8. Control minus natural vegetation run inner-domain areaaveraged (a) 2-m temp, (b) surface latent heat, and (c) moisture flux at $500 \mathrm{~m}$.

cover from the Kuchler vegetation dataset (Fig. 2c). In the control and OGE wet run simulations, the topsoil of the areas under irrigation, up to a depth of $0.2 \mathrm{~m}$, was saturated at 0000 UTC each day for the duration of the experiment (1-15 July 1997). In both the OGE dry and natural runs, the soil was allowed to dry out, except when replenished naturally by rainfall.

The "soil wetting" procedure for the control and
OGE wet runs was constructed to imitate the centerpivot irrigation scheduling under dry synoptic atmospheric conditions such as observed in Nebraska during the first half of July 2000 (i.e., little or no rainfall recorded throughout the state). The observed atmospheric conditions from the National Centers for Environmental Prediction (NCEP) reanalysis data (Kalnay et al. 1996) were used to create identical lateral boundary conditions in the four cases. We adopted a two-grid nested model domain configuration with a $10-\mathrm{km}$ grid centered over Nebraska nested inside a larger 40-km grid, which extends over most of the central United States (Fig. 3). Both grids used 30 vertical levels that were stretched from the first model level $(50 \mathrm{~m})$ by $100-\mathrm{m}$ vertical spacing closer to the ground to $1 \mathrm{~km}$ near the model top at $18 \mathrm{~km}$. The coarse grid had 70 grid cells in the $x$ and 35 in the $y$ directions while the fine grid had 90 and 42 grid cells in the $x$ and $y$ directions, respectively. A 1-min time step was used on the coarse grid and 15 $\mathrm{s}$ on the fine grid. A modified Kuo cumulus parameterization scheme (Tremback 1990) and the Chen and Cotton (1983) radiative transfer scheme were employed. We used 11 vertical soil layers and the soil was assumed to be sandy clay loam throughout the model domain. The soil moisture field was initialized across the domain based on July 1997 model-estimated soil moisture values obtained from the NCEP soil moisture database.

\section{Results and discussion \\ a. Validation of model results}

National Climate Data Center (NCDC) archived observations of daily maximum, minimum, and dewpoint temperature for several stations located within the inner model domain were used to validate the model output. Surface $(2 \mathrm{~m})$ temperature and dewpoint data from inner-domain grid cells centered over the climate stations were extracted and compared to the time series of the observations. RAMS postprocessing routines were used to obtain the 2-m model temperature based on the Louis (1979) similarity theory formulation over bare soil and vegetated surfaces. The comparison of the control run output and station data at two of the stations used in the validation-Omaha/Eppley Field $\left(41.18^{\circ} \mathrm{N}\right.$, $\left.95.55^{\circ} \mathrm{W}\right)$ and Ainsworth municipal $\left(42.35^{\circ} \mathrm{N}, 100^{\circ} \mathrm{W}\right)$ are presented in Figs. 4 and 5. The model performed quite well in capturing both the amplitudes and temporal trend of observed temperature and dewpoint temperature for 1-15 July 1997 at the two locations. The correlations ( $r$ values) between model and observations ranged from 0.83 (maximum temperature at Ainsworth) to 0.92 (maximum temperature at Omaha). Sensible and latent heat flux measurements made at several Nebraska tallgrass prairie locations during the peak growing season months of July and August (Verma et al. 1989) were also compared to the control run surface fluxes. Although these measurements were made for years other 
TABLE 2. List of station data locations and associated land uses.

\begin{tabular}{|c|c|c|c|c|}
\hline Station name & County & Land use & Station status & Length of data record \\
\hline York & York & Irrigated & $\mathrm{HCN}$ & $1901-2000$ \\
\hline Osmond & Pierce & Irrigated & Cooperative & $1948-2000$ \\
\hline Oakdale & Antelope & Irrigated & $\mathrm{HCN}$ & $1893-2000$ \\
\hline Box Butte & Box Butte & Irrigated & Cooperative & $1948-81$ \\
\hline Halsey & Thomas & Dry land & $\mathrm{HCN}$ & $1903-2000$ \\
\hline Chadron & Daws & Dry land & Cooperative & $1948-2000$ \\
\hline Auburn & Nemaha & Dry land & $\mathrm{HCN}$ & $1900-2000$ \\
\hline Valentine airport & Cherry & Dry land & Cooperative & $1948-2000$ \\
\hline Alliance & Box Butte & Irrigated & $\mathrm{HCN}$ & $1900-2000$ \\
\hline
\end{tabular}

than 1997, the magnitudes of observed fluxes were comparable to the model output for grid cells centered over the measurement sites (not shown).

\section{b. Model domain averages}

Results for the inner-domain area-averaged model parameters between the control run and OGE wet run (Fig. 6) showed very moderate differences (see Table 1 for summary of scenario comparisons). This reflects the rather small change (less than $10 \%$ ) in the irrigated portion of the OGE vegetation data (Fig. 2b) compared to the more recent Landsat-satellite-based land cover estimates (Fig. 2a). In both simulations, the soil-wetting procedure was implemented for the irrigated areas (i.e., land use class 16 in LEAF-2). Larger changes were observed when the control run was compared to the OGE dry run: midsummer 2-m temperature over $\mathrm{Ne}$ braska might be cooler by as much as $3.4^{\circ} \mathrm{C}$ under current conditions (Fig. 7a). The average difference between the control and OGE dry runs computed for the 6-15 July 2000 period was $1.2^{\circ} \mathrm{C}$. The irrigation-induced surface cooling was accompanied by a $36 \%$ increase in the surface latent heat flux (Fig. 7b) and a significant increase in (28\%) water vapor flux at $500 \mathrm{~m}$ above the ground (Fig. 7c). A corresponding reduction

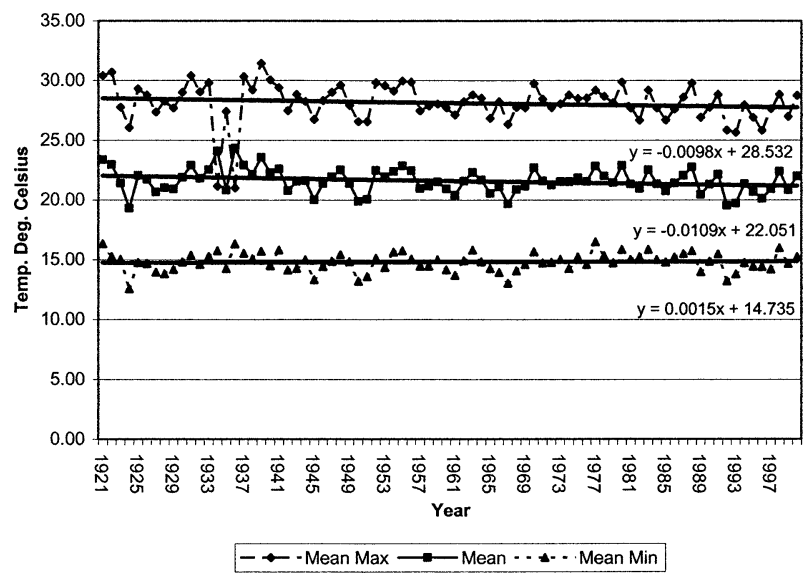

FIG. 9. May-Sep York, NE, mean max temp, mean temp, and mean min temp: 1921-2000. in surface sensible heat $(15 \%)$ and a $2.6^{\circ} \mathrm{C}$ elevation in dewpoint temperature were also observed (not shown).

The cooling effect and the surface energy budget differences identified above intensified in magnitude when the control run results were compared to the potential natural vegetation scenario. For example, the nearground average temperature for 6-15 July 2000 was $3.3^{\circ} \mathrm{C}$ cooler, the surface latent heat flux was $42 \%$ higher, and the water vapor flux (at $500 \mathrm{~m}$ ) $38 \%$ greater in the control run compared to the natural landscape run (Figs. $8 \mathrm{a}-\mathrm{c})$. We excluded the first 5 days of the simulation in computing this temporal average because a fairly strong midlevel low stalled over the study area during that period. This synoptic environment was responsible for the unusual depression in both the minimum and maximum temperatures recorded in the early part of July 2000 in Nebraska (Figs. 4a and 5a).

Important physical changes between the natural shortgrass prairie of this region and the current land use patterns include alterations in the surface albedo, roughness length changes, and increased soil moisture in the irrigated areas. These changes are capable of generating complex changes in the lower atmosphere (PBL) energy budget. For example, the simulated increase in the portion of the total available energy being partitioned into latent heat rather than sensible heat resulted directly

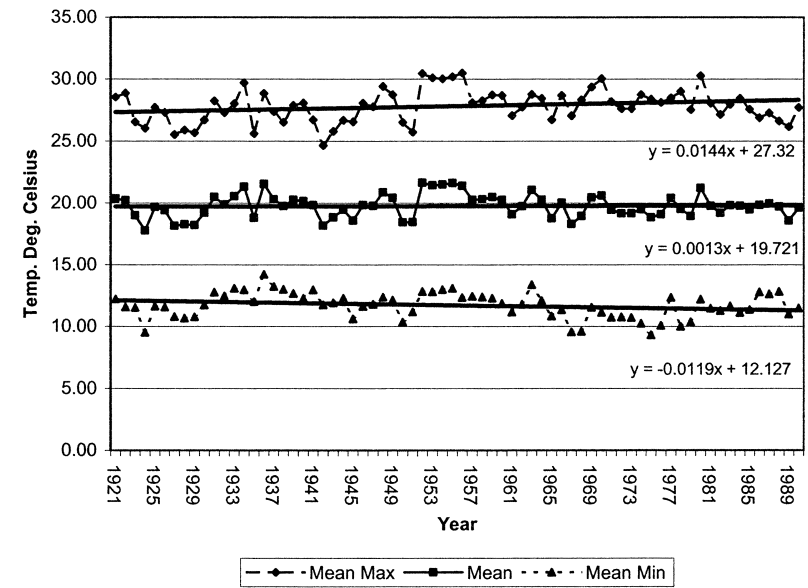

FIG. 10. May-Sep Halsey, NE, mean max temp, mean temp, and mean min temp: 1921-2000. 


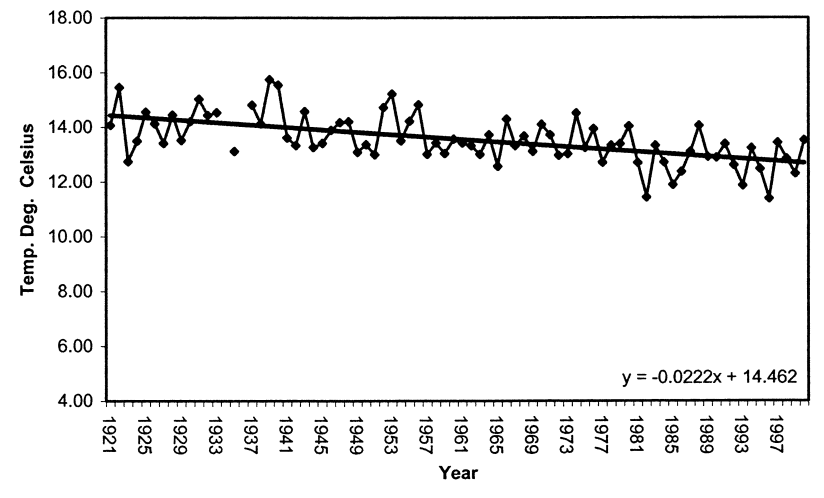

FIG. 11. May-Sep York, NE, temp range (mean max temp - mean min temp): 1921-2000.

from the enhanced transpiration and soil evaporation in the control run. Although not examined in detail in this study, elevated dewpoint temperature and moisture fluxes within the PBL can increase the convective available potential energy, promote atmospheric instability, and enhance daytime cloud cover (Stohlgren et al. 1998). Localized extreme dewpoints, which do not appear to be advected from the Gulf of Mexico, are increasingly being observed in the central United States especially during hot summer periods. These are most likely related to changing agricultural practices, including increased evaporation from irrigation.

An increase in evaporative fraction over irrigated areas could induce changes in the equivalent potential temperature and ultimately trigger convention. However, the associated changes in the convective available potential energy (CAPE) necessary for convection may not always be realized, especially under very dry conditions similar to the situation in Nebraska for most of the duration of our modeling experiment. In our control run (i.e., current vegetation with daily soil wetting at 0000 UTC), we observed that there was no significant precipitation for most of the simulated period, except the last 3 days (13-15 July 1997), with amounts ranging between 1 and 3 in. occurring almost exclusively in the irrigated portions of the state. Nonirrigated areas generally recorded less than 0.7 in. of rain on those 3 days. Station precipitation data follow the same temporal and spatial trend, except that the maximum recorded precipitation during this 3 -day period was 2.3 in. at a station (North Platte; $41^{\circ} \mathrm{N}, 100^{\circ} \mathrm{W}$ ) adjacent to irrigated fields. RAMS overestimates this precipitation amount by about 1.3 in., but captures the spatial distribution quite well.

While the reported changes in model parameters due to irrigation in this study may be large, the primary physical process involved in the changes is a repartitioning of sensible and latent heat fluxes in the irrigated areas of the model domain. Moreover, added wetness could cause the environment to nonlinearly respond by producing a proportion of rain (and associated model parameters) that is greater in percent than the actual percent of land use change. Previous RAMS simulations for the central plains and the foothills of the Rocky Mountains showed that an increase in moisture and energy can increase the intensity of summer thunderstorms in those areas (Copeland et al. 1996; Chase et al. 1996). Temporal and spatial analyses of long-term (1921-2000) climate data in Nebraska appear to provide corroborating evidence of regional irrigation-induced cooling in the summer. The results of those analyses are presented in the following section.

\section{c. Surface climate analyses}

The effects of irrigation-induced changes to the partitioning of the total available energy at the surface, indicated in the preceding section, should be reflected in screen height $(\sim 2 \mathrm{~m})$ air temperature data at stations located within heavily irrigated areas. Specifically, daily maximum temperature should decrease under extensive irrigation because of the reduction in sensible heat flux into the lower atmosphere. We conducted a statistical analysis of long-term (1921-2000) surface temperature from five irrigated and two nonirrigated sites (Table 2) in Nebraska to test this hypothesis. These sites include cooperative and Historical Climate Network (HCN) stations with surface climate data dating back to the early 1900s. We present results from two sites: York (located in eastern Nebraska; $40.86^{\circ} \mathrm{N}, 97.59^{\circ} \mathrm{W}$ ) and Halsey (located in west-central Nebraska; $\left.41.9^{\circ} \mathrm{N}, 100.31^{\circ} \mathrm{W}\right)$. The sites represent locations of extensive irrigated and nonirrigated land uses, respectively and they are representative of the overall findings from the station climate data analyses.

May through September is the main growing season in Nebraska and is therefore the period when impacts of energy partitioning on air temperature would be strongest. Growing season monthly mean and monthly mean maximum temperature data for York show a steady decreasing trend (Fig. 9) while a nonirrigated site (Halsey) shows an increasing trend in monthly mean maximum temperature (Fig. 10). On the other hand, minimum temperature shows very little change in trend over time at both sites (Figs. 9 and 10). The monthly mean maximum temperature appears to be the dominant factor causing the decreasing trend in monthly mean temperature (Fig. 9) and mean temperature range (Fig. 11) at the York location. A possible reason for this decreasing trend in near-surface temperature may be the post-1950 massive increase in irrigated agriculture in York County, although variations in cloud cover persistence could also be a contributing factor. To further investigate the possible impact of land use on the temperature record, we analyzed the temperature record separately for the preirrigation (1921-50) and irrigation (1950-2000) periods. Temperature averages for the two time periods (Table 3 ) indicate lower mean and maximum temperature values for the second half of the twen- 
TABLE 3. Average temp for York and Halsey, NE.

\begin{tabular}{lccc}
\hline \hline \multicolumn{1}{c}{ Location } & Mean temp & $\begin{array}{c}\text { Mean max } \\
\text { temp }\end{array}$ & Mean min temp \\
\hline York (1921-50) & 21.89 & 28.25 & 14.77 \\
York (1951-2000) & 21.44 & 28.06 & 13.25 \\
Halsey (1904-50) & 19.50 & 27.38 & 11.61 \\
Halsey (1951-90) & 19.90 & 28.27 & 11.52 \\
\hline
\end{tabular}

tieth century at York and higher values at Halsey. While this decreasing trend in temperature at the heavily irrigated York site is not conclusive evidence of an irrigation-induced effect, it does suggest a role for localscale factors, including land use change, in influencing the temperature regime in this area.

\section{Conclusions}

The analyses of domain-averaged surface temperature and surface fluxes presented in this study clearly indicate that key components of the planetary boundary layer, particularly the partitioning of the available surface energy, in this region are very sensitive to changes resulting from increased irrigation. RAMS simulations forced, in part, by four different land cover scenarios indicate a cooling in the near-ground temperature, and significant increases in vapor and latent heat fluxes into the atmosphere in response to this human disturbance of the landscape. These changes are shown to be related to the conversion of the natural prairie vegetation in this region to irrigated and dry cropland. Corroborating evidence from analyses of long-term surface climate data indicates a steady decreasing trend in mean and maximum air temperature at locations located within heavily irrigated areas thus confirming the irrigation-induced cooling effect suggested by the RAMS simulations.

Acknowledgments. This work is funded in part by the USGS EROS Data Center under Contract 1434-CF-97AG-00025 and by the NSF (Grant DEB9632852). Support was also provided by the Colorado Climate Center and the Cooperative Institute for Research in the Atmosphere (CIRA) at Colorado State University. We also thank Markus Tooze and Christy Carson for their assistance with data analysis.

\section{REFERENCES}

Alpert, P., and M. Mandel, 1986: Wind variability-An indicator for mesoclimatic change in Israel. J. Climate Appl. Meteor., 25, $1568-1576$.

Barnston, A. G., and P. T. Schickendanz, 1984: The effect of irrigation on warm season precipitation in the southern Great Plains. $J$. Climate Appl. Meteor., 23, 865-888.

Betts, A. K., J. H. Ball, A. C. M. Beljaars, M. J. Miller, and P. Viterbo, 1994: Coupling between land-surface boundary-layer parameterization and rainfall on local and regional scales: Lessons from the wet summer of 1993. Preprints, Fifth Conf. on Global Change Studies, Nashville, TN, Amer. Meteor. Soc., 174-181.

Chase, T. N., R. A. Pielke Sr., T. G. F. Kittel, R. Nemani, and S. W.
Running, 1996: The sensitivity of a general circulation model to large-scale vegetation changes. J. Geophys. Res., 101, 7393 7408.

- , R. A. Pielke, T. G. F. Kittel, R. R. Nemani, and S. W. Running, 2000: Simulated impacts of historical land cover changes on global climate in northern winter. Climate Dyn., 16, 93-105.

Chen, C., and W. R. Cotton, 1983: A one-dimensional simulation of the stratocumulus-capped mixed layer. Bound.-Layer Meteor., 25, 289-321.

Copeland, J. H., R. A. Pielke, and T. G. F. Kittel, 1996: Potential climatic impacts of vegetation change: A regional modeling study. J. Geophys. Res., 101, 7409-7418.

De Ridder, K., and H. Gallée, 1998: Land surface-induced regional climate change in southern Israel. J. Appl. Meteor., 37, 14701485 .

Eastman, J. L., M. B. Coughenour, and R. A. Pielke Sr., 2001: Does grazing affect regional climate? J. Hydrometeor., 2, 243-253.

Grell, G. A., J. F. Dudhia, and D. Stauffer, 1993: A description of the fifth generation Penn State/NCAR Mesoscale Model (MM5). NCAR Tech. Note NCAR/TN-398+IA, 107 pp. [Available from National Center for Atmospheric Research, P. O. Box 3000, Boulder, CO 80307-3000.]

Heck, P., D. Luthi, H. Wernli, and C. Schar, 2001: Climate impacts of European-scale anthropogenic vegetation changes: A sensitivity study using a regional climate model. J. Geophys. Res., 106, 7817-7835.

Kalnay, E., and Coauthors, 1996: The NCEP/NCAR 40-Year Reanalysis Project. Bull. Amer. Meteor. Soc., 77, 437-471.

Kuzelka, R. D., 1993: Introduction. Flat Water: A History of Nebraska and its Water, C. A. Flowerday, Ed., University of Nebraska Conservation and Survey Division Resources Rep. 12, $1-7$.

Louis, J. F., 1979: A parametric model of vertical eddy fluxes in the atmosphere. Bound.-Layer Meteor., 17, 187-202.

Marotz, G. A., J. Clark, J. Henry, and R. Standfast, 1975: Cloud fields over irrigated areas in southwestern Kansas-Data and speculations. Prof. Geogr., 27, 457-461.

National Agricultural Statistics Service, 1998: Crop values: Final estimates by states, 1992-97. Statistical Bull. Agricultural Statistics Board, U.S. Department of Agriculture, 963. [Available online at http:www.usda.gov/nass/pubs/agr98/acro98.htm.]

Pielke, R. A., Sr., 2001: Influence of the spatial distribution of vegetation and soils on the prediction of cumulus convective rainfall. Rev. Geophys., 39, 151-177.

Pielke, R. A., Sr., and X. Zeng, 1989: Influence on severe storm development of irrigated land. Natl. Wea. Dig., 14, 16-17.

_ , and Coauthors, 1992: A comprehensive meteorological modeling system-RAMS. Meteor. Atmos. Phys., 49, 69-91.

Segal, M., Z. Pan, R. W. Turner, and E. S. Takle, 1998: On the potential impact of irrigated areas in North American summer rainfall caused by large-scale systems. J. Appl. Meteor., 37, 325331.

Stohlgren, T. J., T. N. Chase, R. A. Pielke, T. G. F. Kittel, and J. Baron, 1998: Evidence that local land use practices influence regional climate and vegetation patterns in adjacent natural areas. Global Change Biol., 4, 495-504.

Tremback, C. J., 1990: Numerical simulation of a mesoscale convective complex: Model development and numerical results. $\mathrm{Ph}$. D. dissertation, Colorado State University, $187 \mathrm{pp}$.

Verma, S. B., J. Kim, and R. J. Clement, 1989: Carbon dioxide, water vapor and sensible heat fluxes over a tall grass prairie. Bound. Layer Meteor., 46, 53-67.

Walko, R. L., C. J. Tremback, R. A. Pielke, and W. R. Cotton, 1995: An interactive nesting algorithm for stretched grids and variable nesting ratios. J. Appl. Meteor., 34, 994-999.

, and Coauthors, 2000: Coupled atmosphere-biophysics-hydrology models for environmental modeling. J. Appl. Meteor., 39, 931-944.

Williams, J. H., and S. Murfield, 1977: Agricultural Atlas of Nebraska. University of Nebraska Press, $215 \mathrm{pp}$. 